\title{
Conceptualising cosmopolitanism and entrepreneurship through the lens of the three- dimensional theory of power
}

Nikolai Mouraviev, and Nada K. Kakabadse

This is the author's final version of this article. (C) Emerald Group Publishing, permission has been granted for this version to appear here: https://repository.abertay.ac.uk/jspui/. Emerald does not grant permission for this article to be further copied/distributed or hosted

elsewhere without the express permission from Emerald Group

Publishing Limited. - See more at:

http://www.emeraldgrouppublishing.com/authors/writing/author right

s.htm

The final published version is available from doi: $10.1108 /$ SBR-12-

$\underline{2015-0071}$ 


\title{
Conceptualising cosmopolitanism and entrepreneurship through the lens of the three-dimensional theory of power
}

\author{
Nikolai Mouraviev, PhD \\ Senior Lecturer in Business and Management \\ Dundee Business School \\ Abertay University \\ Dundee \\ United Kingdom \\ Professor Nada K. Kakabadse \\ Henley Business School \\ University of Reading \\ Henley-on-Thames \\ United Kingdom
}

\begin{abstract}
Purpose - The paper aims to conceptualise cosmopolitanism drivers from the third-level power perspective by drawing on Lukes' $(1974 ; 2005)$ theory of power. In addition, the paper aims to investigate the relationship between entrepreneurs' cosmopolitan dispositions and habitus, i.e. a pattern of an individual's demeanour, as understood by Bourdieu.

Design/methodology/approach - This conceptual paper makes use of Bourdieu's framework (habitus) by extending it to the urban cosmopolitan environment and linking habitus to the threedimensional theory of power and, importantly, to the power's third dimension - preferenceshaping.

Findings - Once cosmopolitanism is embedded in the urban area's values, this creates multiple endless rounds of mutual influence (by power holders onto entrepreneurs via political and business elites, and by entrepreneurs onto power holders via the same channels), with mutual benefit. Therefore, mutually beneficial influence that transpires in continuous support of a cosmopolitan city's environment may be viewed as one of the factors that enhances cosmopolitan cities' resilience to changes in macroeconomic conditions.
\end{abstract}


Originality/value - The paper offers a theoretical model that enriches the understanding of the power-cosmopolitanism-entrepreneurship link, by emphasising the preference-shaping capacity of power, which leads to the embedment of cosmopolitanism in societal values. As a value shared by political and business elites, cosmopolitanism is also actively promoted by entrepreneurs through their disposition and habitus. This ensures not only their willing compliance with power and the environment, but also their enhancement of favourable business conditions. Entrepreneurs depart from mere acquiescence (to power and its explicit dominance), and instead practice their cosmopolitan influence by active preference-shaping.

Keywords - Cosmopolitanism, power, habitus, cosmopolitan disposition, entrepreneurship

Paper type - Conceptual paper

\section{Introduction}

Political, economic, business and social processes in nations worldwide are influenced both by globalisation processes and growing cosmopolitanism. Whilst globalisation should be viewed as more than simply an ability to engage in transactions across national borders (Spring, 2008), it is a process that has at least two dimensions: (a) external influences and (b) internal responses (Douglass, 2005). In globalisation processes, standardisation (i.e. standardised deployment of readily available solutions in politics, economics, commerce, banking, education, social structures and cultural approaches) prevails over nation-specific, contextually- and culturallydriven choices (Enders, 2004). In globalisation, worldwide trends dominate over locally-rooted processes.

In contrast to globalisation, cosmopolitanism allows individual values and individualised solutions, whilst actors including citizens, businesses, interest groups, governments and NGOs have a general agreement regarding diversity as a norm (Woodward et al., 2008). Paying respect to the differences and being fully aware of interdependence, allows actors to create governance of diversity (Appiah, 2006). Globalisation and cosmopolitanism each have their own drivers and underlying dynamics. Whilst globalisation is often driven by external impulses complemented by domestic policies (which still need to be investigated), this paper intends to contribute to a deeper conceptualisation of cosmopolitanism by analysing cities that have formed, or are 
forming, an environment that matches the cosmopolitanism' principal feature, i.e. governance of diversity for the common good. The paper highlights the social norms and social forms that are critical for cosmopolitan cities and that cities create and benefit from.

Around the world, the development of cities and regions has shown significant variation in advancing entrepreneurship, promoting growth, and ensuring economic, social and environmental sustainability. Whilst city governments are keen, typically, on attracting investment, enhancing private enterprise and fostering economic growth, their success rates are different: some exhibit sustainable growth over lengthy periods, whilst the vulnerability of others shows their dependency on macroeconomic trends and changes in these trends. Cities with a largely cosmopolitan environment, such as Auckland, Berlin, Dubai, Edinburgh, Hong Kong, London, New York, Shanghai or Singapore, are successfully developing and attracting entrepreneurs from all over the world, even during the economic downturn (Sennett, 2002; Smith, 2007; Brooks, 2013; www.city-data.com). Naturally, these cities may also experience a level of economic decline during recession; however, their resilience to downward trends in their nation's economy is remarkably strong, and their ability to sustain entrepreneurship and growth remains high. This raises a host of questions regarding these cities' commonalities, and the reasons for their success. Are these cities cosmopolitan? What are the essential features of their environment that make it cosmopolitan? Furthermore, are there links between a cosmopolitan environment and effective urban development?

The extant literature is silent regarding the relationship between cosmopolitanism, entrepreneurship (a key driver of economic growth), urban environment and sustainable development. Whilst the body of knowledge about cosmopolitanism is growing, scholars attempt to conceptualise cosmopolitanism from certain angles including the sociological perspective, cultural adaptation, or via studies of entrepreneurs who take advantage of networking opportunities that cosmopolitan environments offer (for example, see Jack et al., 2004; De Clercq and Voronov, 2009; Kendall et al., 2009; Delanty, 2012). However, the literature would benefit from comprehensive studies that provide a detailed account of the cosmopolitan environment's features and how they evolve, explain whether or not this environment fosters entrepreneurship and, ultimately, how it contributes to resilience of cosmopolitan urban areas. Whilst cosmopolitanism may be observed in various environments, its most salient manifestations can be noted in large urban areas that demonstrate flourishing entrepreneurship, a 
large number of international firms, a high percentage of foreign-born resident population and foreign nationals who do business. Therefore, the gap that this paper aims to address, at least in part, refers to the explanation of what constitutes a cosmopolitan city, how entrepreneurs perceive its traits and themselves in a cosmopolitan environment, and, specifically, how entrepreneurs perceive and collaborate with the power holders. As a city's development heavily depends upon entrepreneurship, this paper's significance is justified by noting the existence of a direct link between sustainable urban growth and the cosmopolitan environment that feeds entrepreneurship.

This paper argues that the unique character of certain urban areas makes them attractive to entrepreneurs from different nations, regardless of macroeconomic fluctuations in the business cycle. Furthermore, the distinct cosmopolitan environment of these urban areas ensures economic growth, even in times of recession. Hence, an understanding of the interplay between cosmopolitanism and entrepreneurship is critical in identifying how cities can ensure sustainable development. Additionally, the factors that facilitate cosmopolitanism merit exploration. As each city has its own contextual environment, this suggests that cosmopolitanism is, inevitably, locally grounded, although one can hardly dispute its international orientation. Whilst the urban context that contributes to cosmopolitanism deserves investigation from a variety of perspectives, for this paper the authors have chosen the power perspective and, more specifically, the three-dimensional view of power (Lukes, 2005).

This paper aims to conceptualise cosmopolitanism drivers from the third-level power perspective, drawing on Lukes' theory of power (Lukes, 2005). Additionally, the paper investigates the relationship between entrepreneurs' cosmopolitan dispositions and habitus, i.e. a pattern of an individual's demeanour, as conceptualised by Bourdieu (1977; 1990). The paper makes use of Bourdieu's framework (habitus) by extending it to the urban cosmopolitan environment and linking habitus to the three-dimensional theory of power.

The paper begins by highlighting the meaning of cosmopolitanism, cosmopolitan disposition and habitus. It then develops a theoretical model that enables an understanding of how power and the powerful shape cosmopolitanism and, ultimately, urban development. The paper outlines the principal elements of a cosmopolitan disposition and the critical factors in influencing the powerful. The paper's conclusion draws insights into how cosmopolitanism may become a more effective tool for entrepreneurship and urban development. 


\section{Cosmopolitanism as an identity, identity transformation and value}

In conceptualising cosmopolitanism, this paper draws on Douzinas' (2007) view that cosmopolitanism forms an identity that is signified by an individual's departure from the fixed spatio-temporal dimension to the bigger world and that "cosmopolitanism is about sameness, difference and values themselves" (Douzinas, 2007, p. 175). For example, cosmopolitan entrepreneurs exhibit similar behaviours, attitudes, and a high degree of adaptability as they easily move from one location to another and take advantage of a favourable environment for doing business. They are naturally different from each other from the perspective of their educational and cultural background and how they do business, although it is likely that their perceptions of risk, opportunities and appropriate management practices are similar, as they show transnational, rather than domestic, orientation and learn from each other (Drori et al., 2009; Honig et al., 2010). As for values, cosmopolitanism forms a set of attitudes, behaviours and practices, among which society's openness to entrepreneurship is critical (Kendall et al., 2009). Other significant cosmopolitanism features are attitudes to, and appreciation of, human rights, social diversity, global environmental protection, consumption, and aesthetics (Woodward et al., 2008). Furthermore, cosmopolitan values include social inclusion and tolerance (Jack et al., 2004; Honig et al., 2010).

Whilst cosmopolitanism is, in Socrates' words, an identity of a "citizen of the world" (Kakabadse and Kakabadse, 2012), it also implies identity transformation. Cosmopolitanism may involve the active construction of social forms that benefit cosmopolitan individuals. An example of these social forms is a power structure, such as a municipal agency charged with responsibility for urban development and attracting private investment. The agency's performance is likely to be assessed by the level of investment it brings to the city and how many companies are formed during a year. Therefore, in order to be successful, it has to provide benefits to entrepreneurs and create an environment that is attractive to not only businesses from its home country, but also to entrepreneurs from any other nation (Anderson et al., 2010; Honig et al., 2010; Igarashi and Saito, 2014). The construction of social forms that reinforce and enhance openness, behaviours (e.g. swift decision-making), attitudes (e.g. accepting diversity as a norm) and practices (e.g. CSR actions) may be viewed as the process of value creation, in which institutional structures evolve and strengthen a cosmopolitan disposition and cosmopolitan 
values (Woodward and Skrbiš, 2012). Hence, in a certain context, in which cosmopolitanism is a value, social structures become cosmopolitan (Beck, 2006) and work towards identity transformation. This furthers the urban area's cosmopolitan orientation, the core of which is transformation of identities, both human and organisational, in the direction of greater openness and an ever-increasing appreciation of cosmopolitan attitudes, behaviours and values.

Cosmopolitanism also implies disposition and habitus. The cosmopolitan disposition may be viewed as a habitual inclination or tendency to do things in a certain way, or to exhibit a certain pattern of behaviour that is aligned with openness and other cosmopolitan values. The cosmopolitan disposition is part of habitus, which is defined as the interplay of dispositions and structures over time (Bourdieu, 1984). Aristotle's concept of habitus, re-worked by Aquinas and revived by a sociologist (Mauss) and philosopher (Merleau-Ponty), has subsequently been advanced and used by sociologist and anthropologist Bourdieu as an analytical tool for understanding the cognitive components of action (Lizardo, 2004). Aristotle's notion of habitus is conceptualised as hexis (the Latin translation of a Greek word), which refers to the state of possessing (or 'having', Latin habere) an acquired, trained disposition to engage in certain modes of activity when encountering particular situations (Lizardo, 2004).

Habitus refers to how "society becomes deposited in persons in the form of lasting dispositions, or trained capacities and structured propensities to think, feel and act in determinant ways, which then guide them" (Wacquant, 2005, p. 316). Bourdieu (1984) argues that habitus is created unconsciously over a lengthy period of time, "without any deliberate pursuit of coherence... without any conscious concentration" (Bourdieu, 1984, p. 170). Bourdieu's habitus is the product of adaptation to a variety of conditions in the environment. Habitus implies that a person re-creates the very same conditions under which the set of skills and dispositions that are constitutive of it can be most profitably put to use. Conversely, habitus predisposes a person to avoid those environments and situations for which he is not well equipped. This is echoed by Brubaker (1993) who also notes a lack of deliberate actions in the formation of habitus by suggesting, "habitus governs practice in a subconscious, unreflective manner" (Brubaker, 1993, p. 225). Nonetheless, Bourdieu (1984), Brubaker (1993) and Wacquant (2005) acknowledge that social structures play a certain role in shaping dispositions, and that habitus can change over time. Linking habitus to the three-dimensional theory of power (as discussed in the next section), this paper argues that social structures, such as entrepreneurial and power elites, are likely to 
play a growing role in the formation of cosmopolitan habitus, and conscious actions may significantly shape, strengthen or weaken the cosmopolitan environment in urban areas. The influence of social structures on cosmopolitan habitus depends on whether cosmopolitanism is embedded in society (or, more precisely, in a certain urban area) as its value and, if so, how deeply it is shared by the community.

\section{Theoretical model}

This paper makes use of Lukes' $(1974,2005)$ three-dimensional theory of power and connects it with the concepts of disposition and habitus in the cosmopolitan environment. Power refers to “agents' abilities to bring about significant effects, specifically by furthering their own interests and/or affecting the interests of others, whether positively or negatively" (Lukes, 2005, pp. 6465). One of the critical issues that Lukes (2005) investigates is how the powerful secure the willing compliance of those they dominate. The note about willing compliance is directly linked to the cosmopolitan environment and cosmopolitan mindset, as both cannot evolve without the voluntary engagement of entrepreneurs who are willing to do business internationally, and are comfortable with moving around the world in order to take advantage of newly opened business opportunities.

The three-dimensional theory of power forms the conceptual foundation for this paper. It draws specifically on the third dimension of power and applies power elite's preference-shaping capacity to the urban environment that demonstrates cosmopolitan features. Nourished by power holders, the cosmopolitan environment becomes an attractive and fruitful field for entrepreneurs who both benefit from this environment and contribute to furthering it. Entrepreneurs' disposition and habitus materialise in the cosmopolitan environment and become part of it, whilst the power holders use disposition in order to enhance habitus and transform entrepreneurs' acquiescence into willing compliance with the preferences established by the elite. Figure 1 shows the key concepts that this paper employs. 


\section{Figure 1. Key concepts}

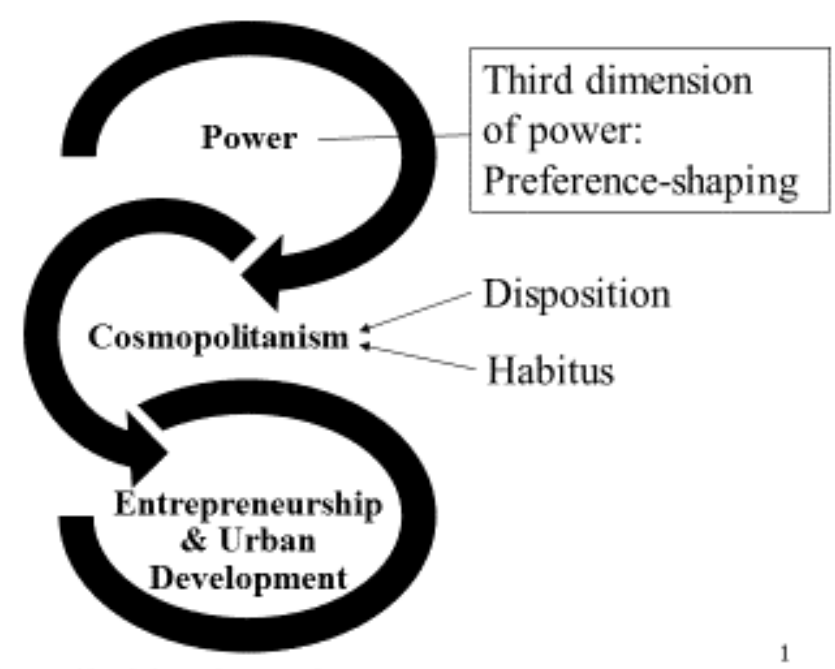

Source: Compiled by the authors.

In the conceptualisation of power, its understanding as a capacity is of particular value for this paper. This is because the capacity to produce a desired effect, adjust self-interests and influence the interests of others, constitute the core of the three-dimensional view of power in which the third dimension-power as preference-shaping-appears critical for the formation of cosmopolitan habitus. The one-dimensional perspective suggests that power is intentional and active (i.e. hard and explicit power, coercive and observable), whilst the two-dimensional view acknowledges that power may also be seen as 'soft' as it is used for agenda-setting (i.e. power appears less visible, such as the power to influence) (Lukes, 2005). The three-dimensional view incorporates into the power relations the preference-shaping capacity of power (i.e. power is invisible and shapes preferences via values, norms and ideologies) (Lukes, 2005). One of the merits of the three-dimensional view is in its departure from the behavioural (i.e. individualistic) focus of power. Instead, this view incorporates social structures and institutional practices into power relations, as it focuses on issues and potential issues, observable and latent conflicts, and subjective and real interests (Lukes, 2005). Whilst the three-dimensional view of power implies recognition that multiple, often competing, interests exist, it also implies that power holders must consider the interests of the dominated, and must deal with the dominated, in order to address their interests and/or to further own interests. 
The three-dimensional theory of power facilitates the capture of the important details of the dominant-dominated relationship. Lukes (2005) calls it the 'supreme' exercise of power when the powerful secure the compliance of the dominated by influencing, shaping and determining their wants and thoughts. Whilst controlling thoughts and desires may take a certain form of coercion, the easier and more effective power relations may stem from the willing compliance of the dominated. Normally, the latter, being subjected to dominance, would not have a choice but to acquiesce in their domination. This type of compliance does not involve the willingness of the dominated, and the implication for societal development is that, inevitably, the dominated adopt a passive role as they become disengaged from the objectives set by the power holders.

Whilst Foucault (1980) rejects the notion that a central ordered and rational agency exists and regulates power, he also views powerlessness as a natural element structured into human existence. Foucault $(1980 ; 1982)$ also asserts that there are no chances of bringing about social change through local efforts, and therefore acquiescence becomes an intrinsic feature of power relations. In contrast to this, Lukes (2005) argues that central authority does exists and the power holders can act rationally to adjust power relations with the powerless. The latter also, in Lukes' (2005) view, can act rationally and purposefully, and can engage in the promotion of certain preferences that suit them.

In order to create a different type of compliance, the powerful may use their preferenceshaping capacity to promote certain values, and embed these values within social structures and institutional practices (Skrbiš and Woodward, 2013). The status of these values, as determined and reinforced by the powerful, is important because it shows to the dominated the value system of power holders, and where a certain value is positioned within the system. As the dominated may take on the values that justify their domination, they may actively promote these values by deliberate actions that further the values, institutionalise them and embed them in everyday life. This type of compliance presents a different kind of power relations that show a departure from mere acquiescence of the dominated. Instead, the dominated become actively engaged in enhancing, institutionalising and internalising the societal values shared by both the powerful and the powerless.

It is worth noting that, in terms of exercising power, the interests of the powerful should be viewed as dynamic and evolving. As they are subject to change, there is no canonical set of 
interests (Lukes, 2005) that would form a permanent stance of the powerful regarding their own desires and values and what values they want the dominated to appreciate and act upon. Neither is there a given set of tools that might be used to ensure continuous compliance of the dominated with the rules, values, standards and structures set by the powerful. Whilst the interests of the latter evolve, they can be influenced, which demonstrates that power is value-dependent. The application of the three-dimensional power theory to cosmopolitanism, therefore, shows that, if cosmopolitanism is valued by society or the community of a certain urban area, power can promote cosmopolitanism. This implies that cosmopolitan entrepreneurs (i.e. the dominated) may not only acquiesce in their domination, but also explicitly benefit from the comfortable urban environment that is favourable for doing business.

The evolving set of interests can be illustrated by Dubai's experience. For a number of years during the 1980s and 90s, Dubai has been successfully developing its financial structure and institutions by inviting both domestic and foreign firms to set up their operations, and by expanding lending and all types of other financial operations. As a result, Dubai has transformed itself into the regional financial centre for both the Persian Gulf nations and for the benefit of local companies that engaged, among many projects, in massive residential and commercial construction in Dubai via the use of affordable financing. This created a win-win situation for Dubai's residents, who are $97 \%$ foreign-born and who are actively engaged in entrepreneurship (Brook, 2013). Multiple benefits for the cosmopolitan city included massive job creation in the financial sector, construction and related industries, which attracted a workforce from all over the world including hired staff and entrepreneurs; plentiful opportunities for investment in developers' business; and sustained economic growth over 20 years. The development of Dubai's financial services and construction has been further expanded by an additional act of critical importance - land reform. Since 2002, foreigners have been allowed to own real estate in Dubai, reform that Dubai has accomplished first among the Gulf nations (Brook, 2013). This radical change created a real estate market in Dubai, which was earlier non-existent as most of land was owned by sheikhs and all others were renters. Owing to the 2002 land reform, anyone can buy a property in Dubai; this has created a real estate boom and boosted inflow of entrepreneurs and investors in the country, whilst making Dubai more cosmopolitan. There is no doubt that the government's action plan evolved over time and this has resulted in considerable 
achievements in the form of a constant influx of entrepreneurs from many nations, and their growing contribution to Dubai's diversity and economic durability.

The deliberate actions of the powerful, intended to create an open entrepreneurial environment and supportive structures (e.g. effective regulatory agencies, streamlined licencing procedures, liberal and transparent tax regimes), form a platform for the willing compliance of the dominated. As such, they are likely to increase entrepreneurs' voluntary engagement with the cosmopolitan environment as the latter brings benefits to their business ( $\mathrm{Li}, 2007$; Thornton and Comberti, 2013). To summarise, being sponsored and formed by the powerful, and aligned with the interests of the dominated, an enhanced cosmopolitan disposition embeds itself in cosmopolitan habitus. This ultimately benefits the power holders via urban economic growth, and entrepreneurs by ensuring profits and sustainability to their business ventures (Dodd et al., 2014).

However, whilst initially the dominant-dominated relationship may be driven principally by the powerful, it may also be driven by the dominated. Keeping in mind that a distinct feature of cosmopolitan entrepreneurs is active opportunity identification on an international scale, their social and political activism (i.e. vigorous efforts to bring about change) becomes a strong force in influencing power holders. Complemented by their wealth and ability to mobilise human and financial resources worldwide, cosmopolitan entrepreneurs may challenge how the dominant political elite uses the third dimension of power, i.e. how parameters of debate and thinking are defined. Whilst a group of entrepreneurs - the most successful, influential and networkedforms the cosmopolitan elite, the latter by itself, much like the powerful, can employ the third dimension of power, i.e. can actively engage in preference-shaping.

Cosmopolitan elite members, as well as all other cosmopolitan entrepreneurs, will be able and willing to shape interests, promote wants and practice their cosmopolitan disposition on their own accord, without the exercise of explicit power by the political elite (the first dimension of power) and/or a pre-determined agenda set by the powerful (the second dimension of power). Due to their own interest in enhancing an open environment and forming the most favourable regime for doing business, cosmopolitans may further this environment autonomously, without direct orders from the top (i.e. without the employment of the third dimension of power). However, they will be significantly more effective if the powerful can deliberately integrate cosmopolitanism into societal or community values as this would facilitate entrepreneurs' 
autonomous acts in the face of incentives set up by others. In the best case scenario, the coordinated actions of the political elite and the cosmopolitan entrepreneurial elite might lead to the establishment of regional and global systems of governance (Held, 2003). The idea of emerging cosmopolitan-driven regional (and international) governance mechanisms is echoed by the notion that cosmopolitanism and, more specifically, cosmopolitan entrepreneurs should be viewed as an evolving institutional structure (Douzinas, 2007) that has a significant capacity to influence political elite and power holders, and engage in preference-shaping in order to promote a cosmopolitan mindset. This is how-through shaping and furthering values and their subsequent institutionalisation - the capacity of the powerless merges with that of the powerful. Not only do the power holders exert their influence, but also they are influenced by the dominated via the same kind of social processes that are embedded in the third dimension of power.

The three-dimensional power framework is useful as it demonstrates that a paradigm shift is required for the effective development of cosmopolitan areas. Instead of (or in addition to) exercising dominance, explicit power and agenda-setting, the powerful should promote values that will be shared by the dominated. Preference-shaping, rather than domination, will facilitate the transition of the powerless from acquiescence to active engagement with the very values that the powerful prefer (Lukes, 2005; Sova et al., 2015). This forms a cycle of influence where the dominated, through the entrepreneurial elite, become able to exert influence on power holders and further enhance the latter's preference-shaping capacity and practice for the benefit of the dominated, the powerful and the community at large (Li, 2007; Sova et al., 2015). Hence, repeat cycles of influence are required in order to ensure the successful advancement of shared values that make cosmopolitan cities' environments most favourable for doing business.

Figure 2 demonstrates how this paper's model evolved as compared to the initial concept reflected in Figure 1. Whilst Figure 1 calls attention to the third dimension of power as the theoretical lens for this paper, Figure 2 emphasises what power's preference-shaping capacity can accomplish - it ensures a paradigm shift from one preference to another (or to an enhanced version of the original preference). By adjusting and furthering a community's preferences, which also cater, fully or in part, to the wants and needs of the powerless, the power elite departs from mere domination. Figure 1 shows that cosmopolitanism is the foundation of the power elite's purposeful actions. Figure 2 captures an enhanced conceptualisation of cosmopolitanism 
as a category that brings mutual benefits - to entrepreneurs, residents, community, and to society at large in the form of business opportunities, durable growth and stability. Therefore, Figure 2 pictures cosmopolitanism in terms of societal value, rather than a mere description of the urban environment. Figure 2 also demonstrates that cosmopolitanism as a shared societal value requires nurturing and enhancement both by power holders and the entrepreneurial elite, which assures that interests of both will be served, and this will lead to the subsequent cycles of adjustment. To reiterate, the cycle of adjustment includes the capture of:

- cosmopolitanism-generated influences on power holders and business people;

- incorporation of these influences in power structures and processes;

- further institutionalisation in the business environment and entrepreneurial attitudes and practices; and

- reflection of newly adopted shared values in an evolved and updated understanding of cosmopolitanism by the vast majority of a certain urban community.

Figure 2 displays the theoretical conceptual model that this paper has developed. 


\section{Figure 2. How power promotes cosmopolitanism}

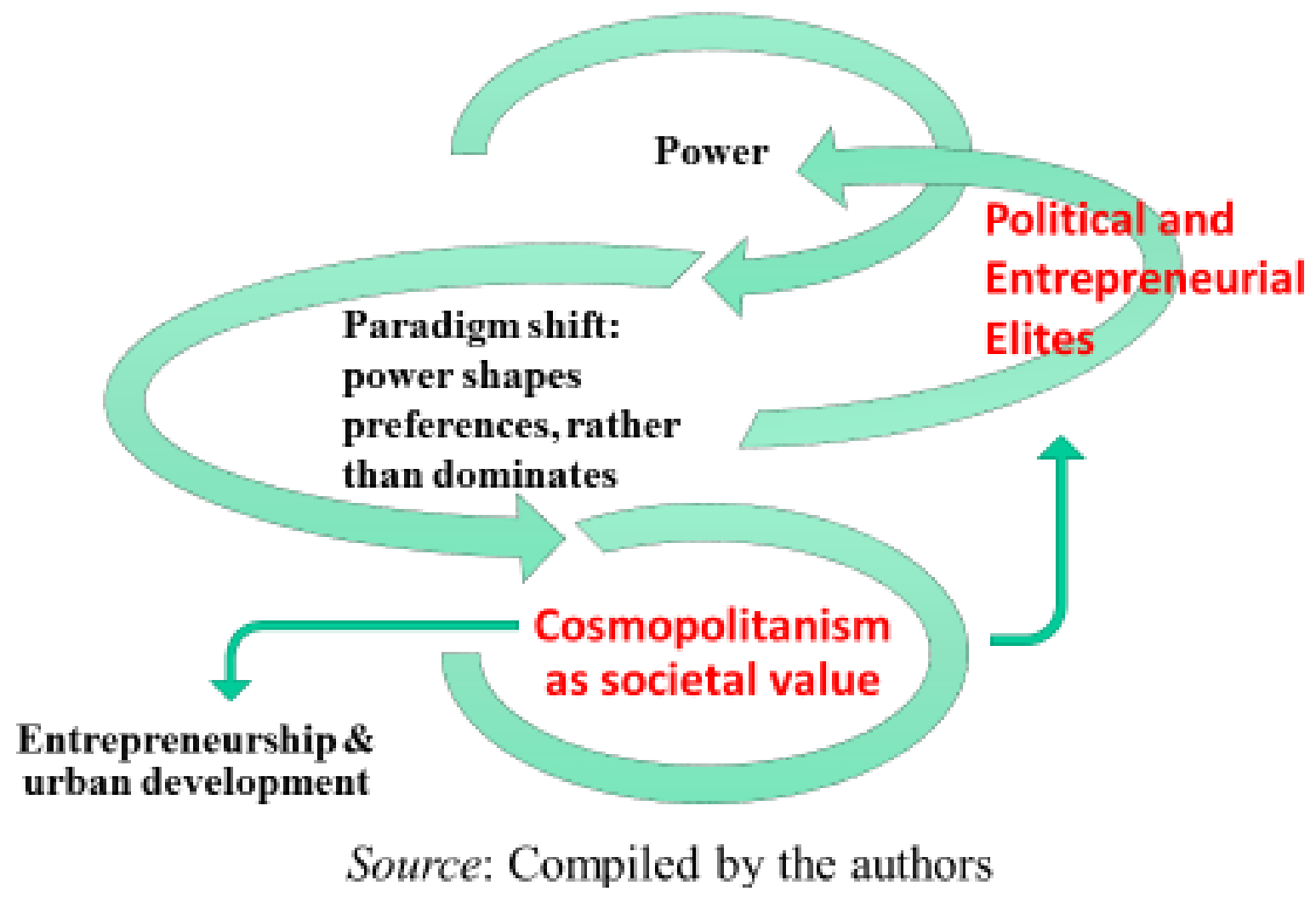

\section{Cosmopolitan disposition, networks and influencing the powerful}

Whilst earlier the paper conceptualised cosmopolitanism as identity and identity transformation, this suggests that the cosmopolitan disposition evolves and can be viewed as a never-ending process (De Clercq and Voronov, 2009; Skrbiš and Woodward, 2013). This raises a question regarding the key elements of the cosmopolitan disposition and the elements of a cosmopolitan disposition that are critical for influencing the powerful.

As this paper views entrepreneurship in select urban areas through cosmopolitan habitus, this means that the entrepreneurs' milieu, i.e. the person's environment, determines the cosmopolitan disposition and the logic that motivates an individual to engage in creative business practice (Bourdieu, 1990; Woodward and Skrbiš, 2012). The entrepreneurs' milieu 
(environment) can be conceptualised as the logic of the field that determines the skills, traits and motivation that a cosmopolitan agent needs to have in order to be successful in the field (Delanty, 2006; Drori et al., 2009). However, the logic of the field should not be understood as a prerequisite for entering the field. An entrepreneur who lacks certain skills or traits still can benefit from the cosmopolitan milieu, and even contribute to its further strengthening, by adopting a cosmopolitan disposition and striving to practice it (Woodward et al., 2008; De Clercq and Voronov, 2009). As this paper's theoretical model argues, a cosmopolitan disposition should not be treated as a given set of rules, norms and values. It can be influenced by the powerful and the values that power holders embed in their milieu, and can also influence the power elites and their preference-shaping.

The cosmopolitan disposition includes core features, such as opportunity identification, and non-core, i.e. less critical features for the field's logic. An example of the latter is educational background (i.e. a specific academic degree) that does not play a critical role in the formation and adoption of a cosmopolitan mindset, and applying it to entrepreneurial practice. Table 1 highlights core characteristics of the cosmopolitan disposition and how they relate to the logic of the field (i.e. the entrepreneurial environment).

\begin{tabular}{|c|c|c|}
\hline & $\begin{array}{l}\text { Entrepreneurs' } \\
\text { cosmopolitan } \\
\text { disposition }\end{array}$ & $\begin{array}{l}\text { The city's milieu: } \\
\text { logic of the field }\end{array}$ \\
\hline $\begin{array}{l}\text { Individual traits (agent's } \\
\text { behavioural pattern) }\end{array}$ & $\begin{array}{l}\text { High degree of } \\
\text { motivation, self-reliance } \\
\text { and adaptability }\end{array}$ & $\begin{array}{l}\text { Integrity and trust } \\
\text { (trustworthy business } \\
\text { relations) }\end{array}$ \\
\hline Structure & $\begin{array}{l}\text { Active engagement in } \\
\text { opportunity identification }\end{array}$ & $\begin{array}{l}\text { Networks (professional, } \\
\text { business, social, political) }\end{array}$ \\
\hline Engagement with milieu & $\begin{array}{l}\text { Orientation on multi- } \\
\text { layered contribution to the } \\
\text { urban environment }\end{array}$ & $\begin{array}{l}\text { Respect for the city's social } \\
\text { and cultural environment }\end{array}$ \\
\hline Cultural identity & $\begin{array}{l}\text { Focus on own } \\
\text { identity - an individual as } \\
\text { part of the world }\end{array}$ & $\begin{array}{l}\text { Tolerance to cultural } \\
\text { differences (i.e. co- } \\
\text { existence) }\end{array}$ \\
\hline
\end{tabular}


Source: compiled by the authors.

Table 1 shows the linkages between an entrepreneur and the urban environment across four dimensions: personal traits, structure, engagement with the environment, and cultural identity. For example, the first dimension-individual traits that form an entrepreneur's behavioural pattern-emphasises a high degree of motivation and adaptability, which is typical for entrepreneurs. At the level of the city, these traits transform into trustworthy business relations, which is a feature of the cosmopolitan environment, and this is how entrepreneurs' individual traits are embedded in the urban cosmopolitan milieu. In other words, entrepreneurs' disposition that was noted in Figure 1 links with the cosmopolitanism of the urban area (Figure 2) and forms habitus as the product of adaptation to conditions in the environment, which is reflected in Table 1 as the city's milieu. An additional example can be drawn from the second dimension, which captures links between an entrepreneur and milieu at the level of structures and institutions. As entrepreneurs are usually actively engaged in opportunity identification (cosmopolitan disposition in Figure 1), in the urban cosmopolitan environment this transforms into extensive networking that creates shared value (see Figure 2) and reveals business opportunities for the benefit of both entrepreneurs and a city (the urban milieu in Table 1). This is the case in many cities, including Dubai, New York and Shanghai.

As cosmopolitan habitus - the logic of the entrepreneurs' milieu-may have varying manifestations in different nations due to unique interplay of cultural traits, government regulations and business practices in a certain economic, social and spatial setting, the critical significance of the urban area's context for the formation of a cosmopolitan mindset must be emphasised. Still, it is likely that the core elements of disposition remain the same across cosmopolitan areas. As Table 1 shows, an entrepreneur's cosmopolitan mindset is closely aligned with the logic of the field (i.e. rules of the city's environment) along four dimensions, which demonstrates the high degree of integration. Hence, a cosmopolitan disposition strengthens entrepreneurial orientation, whilst the latter ensures a continuous inflow of newcomers to the field, who benefit from its cosmopolitan nature and also contribute to its advancement.

The cosmopolitan disposition's feature that ensures an entrepreneur's ability to influence 
the powerful, is active engagement in opportunity identification; often opportunities appear as a result of personal interaction with other businesses, government officials and customers. Table 1 shows that opportunity identification is linked to networks, a critical feature of the cosmopolitan city's milieu (Anderson et al., 2005; 2010). Being integrated with commercial, financial and political networks not only provides an entrepreneur with access to opportunities and resources, but also legitimises an entrepreneur in the cosmopolitan setting as an agent who receives influence from the powerful, and who is embedded in the cosmopolitan networks that are capable of exerting influence on power holders (Anderson et al., 2005; 2010; Jack et al., 2008; Igarashi and Saito, 2014).

This is supported by the notion that entrepreneurs need to concurrently 'fit in' the entrepreneurial process and 'stand out' (De Clercq and Voronov, 2009). Extending this notion, this paper argues that the cosmopolitan environment requires that entrepreneurs legitimise themselves by conforming, in Bourdieu's terminology, to the logic of the field along two critical dimensions. One is engagement in networking; the other is the exercise of the cosmopolitan influence by active preference-shaping. Conforming to the two dimensions ensures that an entrepreneur concurrently 'fits in' and 'stands out'. Acceptance to the networks ensures entrepreneurs' conformity with existing practices and provides them with an opportunity and channels to exert influence on political and business elites. Hence, networks should be viewed as a critical part of milieu and the medium to influence that milieu.

The article has applied the three-dimensional view of power, with an emphasis on its preference-shaping dimension, to the cosmopolitan setting of select urban areas and highlighted how the cosmopolitan environment benefits both entrepreneurs and power holders. Whilst the paper sought to conceptualise the drivers of the development of cosmopolitan areas from the power perspective, revisiting the paper's theoretical framework will now enable us to assess whether it was appropriate in serving the research aim. The paper offers a theoretical model that develops Lukes' (2005) work and appears adequate and instrumental: it enriches the understanding of the power-cosmopolitanism-entrepreneurship link by emphasising the preference-shaping capacity of power, which leads to the embedment of cosmopolitanism in societal values. As a value shared by political and business elites, cosmopolitanism is appreciated and, importantly, actively promoted by entrepreneurs through their disposition and habitus, which ensures not only their willing compliance with power and the milieu, but also 
their enhancement of favourable business conditions. Entrepreneurs depart from mere acquiescence (to power and its explicit dominance) towards practising their cosmopolitan influence by active preference-shaping. Once cosmopolitanism is embedded in societal (ormore precisely - the urban area's) values, this creates multiple endless rounds of mutual influence (by power holders onto entrepreneurs via political and business elites, and by entrepreneurs onto power holders via the same channels), with mutual benefit. Therefore, mutually beneficial influence that transpires in continuous support of a cosmopolitan city's environment may be viewed as one of the factors that enhances cosmopolitan cities' resilience to changes in macroeconomic conditions. Hence, the theoretical perspective taken by the paper appears appropriate and useful for confirming the existence of a link between the cosmopolitan environment and sustainable growth: cosmopolitanism feeds entrepreneurship and, through the latter, may significantly contribute to sustainable urban development.

\section{Conclusion}

Cosmopolitanism may be viewed as a value, not only by entrepreneurs who look for business opportunities around the globe, but also by power holders. The latter may have a high and everincreasing appreciation of cosmopolitanism for two reasons. First, they would welcome to an urban area entrepreneurs with a cosmopolitan mindset, as they facilitate investment, create jobs and increase the region's output. Second, transnational entrepreneurs are those individuals who actively promote cosmopolitanism as a value and, in this capacity, they show not only acquiescence to power structures, but also a willing compliance with existing processes and the desire to improve these processes for their own and common good. This reason may have special significance for power holders as they can fully exercise their third dimension of power, i.e. preference-shaping, for the benefit of society or an area: if cosmopolitanism is valued, power and its holders can further promote cosmopolitanism.

Preference-shaping appears central to the identification of growth drivers in cosmopolitan areas as it manifests itself twice:

- Cosmopolitanism will be most effective when cosmopolitan belief structures are intentionally caused by others, i.e. power holders, and

- As cosmopolitan entrepreneurs may gradually become part of the powerful elite, they can, therefore, increase their own influence on shaping preferences. 
Whilst not every entrepreneur can be considered to be in possession of a cosmopolitan mindset, the importance of networks should not be overlooked. Networks are critical for legitimising cosmopolitan entrepreneurs, as networks are part of milieu and the medium to influence that milieu (Anderson et al., 2005; 2010; Jack et al., 2008). The significance that is attached to networks is aligned with the concept of habitus: cosmopolitanism through international networks contributes towards creating a way of perceiving and acting in the world (i.e. a form of habitus), which facilitates transformation from local to expanded (worldwide) space (Tragardh, 2007).

The paper's conclusion on the significance of preference-shaping in developing and institutionalising cosmopolitan environment has a broader implication of a practical nature for government economic policy. As preference-shaping is driven by a government's long-term political and economic agendas, often economic growth and associated income distribution lie at the core of that government choice. Therefore, cosmopolitanism that leads to sustainable entrepreneurship and steady economic growth may be a preferred solution for urban and/or regional development, once the power holders demonstrate their political will to engage with cosmopolitanism as a value. Further, cosmopolitanism as a shared value might be used as a tool for political governance: as a common platform that unites power holders, business elites, and an urban community at large, cosmopolitanism may ensure a fairer power balance in which voices of entrepreneurs, and the elites that represent them, may be heard and acted upon.

It is worth acknowledging the limitations of this paper, which include the lack of empirical studies to support the paper's observations and conclusions, and also insufficient research into both what constitutes a cosmopolitan city, and how the urban environment interacts with cosmopolitan entrepreneurs. Although cosmopolitan cities have been steadily growing and displaying economic and social durability over recent decades, the properties of co-evolution (entrepreneurs and the urban area) have yet to be studied, which might shed more light on cities' resilience and sustainability. Future research might investigate the interaction between cosmopolitanism and power elites in urban areas and test the conceptual conclusions of this paper. Useful research themes might include the study of the links between the power elite and business elites, how they interact, and the tools they use in order to exercise their preferenceshaping capacity. 


\section{References}

Anderson, A.R., Jack, S.L. and Dodd, S.D. (2005), "The role of family members in entrepreneurial networks: beyond the boundaries of the family firm", Family Business Review, Vol. 18 No. 2, pp. 135-154.

Anderson, A.R., Dodd, S.D. and Jack, S. (2010), "Network practices and entrepreneurial growth”, Scandinavian Journal of Management, Vol. 26 No. 2, pp. 121-133.

Appiah, K.H. (2006), Cosmopolitanism: Ethics in a World of Strangers, Penguin Books, London.

Beck, U. (2006), Cosmopolitan Vision, Polity Press, Cambridge.

Bourdieu, P. (1977), Outline of a Theory of Practice, Cambridge University Press, Cambridge.

Bourdieu, P. (1984), Distinction: A Social Critique of the Judgement of Taste, Harvard University Press, Harvard.

Bourdieu, P. (1990), The Logic of Practice, Stanford University Press, Stanford.

Brook, D. (2013), How Dubai Became Dubai. Next City (Web resource), available at https://nextcity.org/daily/entry/how-dubai-became-dubai (accessed 15 April 2016).

Brubaker, R. (1993), "Social theory as habitus", in Calhoun C., LiPuma, E. and Postone, M. (Eds), Bourdieu: Critical Perspectives, University of Chicago Press, Chicago, pp. 212-234.

De Clercq, D. and Voronov, M. (2009), "The role of cultural and symbolic capital in entrepreneurs' ability to meet expectations about conformity and innovation", Journal of Small Business Management, Vol. 47 No. 3, pp. 398-420.

Delanty, G. (2006), “The cosmopolitan imagination: critical cosmopolitanism and social theory”, The British Journal of Sociology, Vol. 57 No. 1, pp. 25-47.

Delanty, G. (Ed.) (2012), Handbook of Cosmopolitanism Studies, Routledge, London, pp. 127137.

Dodd, S., McDonald, S., McElwee, G. and Smith, R. (2014), "A Bourdieuan analysis of qualitative authorship in entrepreneurship scholarship", Journal of Small Business Management, Vol. 52 No. 4, pp. 633-654.

Douglass, J. (2005). "How all globalization is local: Countervailing forces and their influence on higher education markets", Higher Education Policy Vol. 18 No. 4, pp. 445-473. 
Douzinas, C. (2007), Human Rights and Empire: The Political Philosophy of Cosmopolitanism, Routledge-Cavendish, New York.

Drori, I., Honig, B. and Wright, M. (2009), "Transnational entrepreneurship: an emergent field of study", Entrepreneurship Theory and Practice, Vol. 33 No. 5, pp. 1001-1022.

Enders, J. (2004), "Higher education, internationalization, and the nation-state: Recent developments and challenges to governance theory", Higher Education, Vol. 47 No. 3, pp. 361-382.

Foucault, M. (1980), Power/knowledge: Selected interviews and other writings, 1972-1977, Pantheon Books.

Foucault, M. (1982), “The subject and power”, Critical Inquiry, Vol. 8 No. 4, pp. 777-795.

Held, D. (2003), "Violence, law and justice in a global age", in Archibugi, D. (Ed.), Debating Cosmopolitics, Verso, London.

Honig, B., Drori, I. and Carmichael, B. (Eds) (2010), Transnational and Immigrant Entrepreneurship in a Globalized World, University of Toronto Press, Toronto.

Igarashi, H. and Saito, H. (2014), "Cosmopolitanism as cultural capital: exploring the intersection of globalization, education and stratification", Cultural Sociology, Vol. 8 No. 3 , pp. 222-239.

Jack, S.L., Dodd, S.D. and Anderson, A.R. (2004), "Social structures and entrepreneurial networks: the strength of strong ties", The International Journal of Entrepreneurship and Innovation, Vol. 5 No. 2, pp. 107-120.

Jack, S., Dodd, S.D. and Anderson, A.R. (2008), "Change and the development of entrepreneurial networks over time: a processual perspective", Entrepreneurship and Regional Development, Vol. 20 No. 2, pp. 125-159.

Kakabadse, A. and Kakabadse, N. (2012), Global Elites: The Opaque Nature of Transnational Policy Determination, Palgrave, London.

Kendall, G., Woodward, I. and Skrbiš, Z. (2009), The Sociology of Cosmopolitanism, Palgrave Macmillan, London.

Li, T.M. (2007), The Will to Improve: Governmentality, Development, and the Practice of Politics, Duke University Press, Durham.

Lizardo, O. (2004), “The cognitive origins of Bourdieu's habitus”, Journal for the Theory of Social Behaviour, Vol. 34 No. 4, pp. 375-401. 
Lukes, S. (1974), Power: A Radical View, Macmillan, Basingstoke.

Lukes, S. (2005), Power: A Radical View (2 ${ }^{\text {nd }}$ ed.), Palgrave Macmillan, New York.

Sennett, R. (2002), Cosmopolitanism and the Social Experience of Cities. In: Vertovec, S. and Cohen, R. (eds.) Conceiving Cosmopolitanism. Oxford: Oxford University Press.

Skrbiš, Z. and Woodward, I. (2013), Cosmopolitanism: Uses of the Idea, Sage, London.

Smith, W. (2007), Cosmopolitan Citizenship: Virtue, Irony and Worldliness. European Journal of Social Theory. Vol. 10 No. 1, pp. 37-52.

Sova, C., Vervoort, J., Thornton, T., Helfgott, A., Matthews, D. and Chaudhury, A. (2015), "Exploring farmer preference shaping in international agricultural climate change adaptation regimes", Environmental Science \& Policy, Vol. 54, pp. 463-474.

Spring, J. (2008), "Research on globalization and education", Review of Educational Research, Vol. 78 No. 2, pp. 330-363.

Thornton, T. and Comberti, C. (2013), "Synergies and trade-offs between adaptation, mitigation and development", Climatic Change, DOI 10.1007/s10584-013-0884-3.

Tragardh, L. (Ed.) (2007), State and Civil Society in Northern Europe: The Swedish Model Reconsidered, Berghanh Books, Oxford.

Wacquant, L. (2005), "Habitus”, in J. Becket and Z. Milan (eds.) In International Encyclopaedia of Economic Sociology, Routledge, London.

Woodward, I., Skrbis, Z. and Bean, C. (2008), “Attitudes toward globalization and cosmopolitanism: Cultural diversity, personal consumption and the national economy", The British Journal of Sociology, Vol. 59 No. 2, pp. 207-226.

Woodward, I. and Skrbiš, Z. (2012), "Performing cosmopolitanism", in Delanty, G. (Ed.), Handbook of Cosmopolitanism Studies, Routledge, London, pp. 127-137.

www.city-data.com, Web resource. 